\title{
Poaching of Encephalartos transvenosus, in the Limpopo Province, South Africa
}

\author{
Tshianeo M. Ndou ${ }^{1, *(D)}$, Eduard M. Stam ${ }^{1}$, Milingoni P. Tshisikhawe ${ }^{2}$, Mercy A. Alabi ${ }^{3}$ \\ and Adeyemi O. Adeeyo $4, *$ (D)
}

1 Department of Geography and Environmental Sciences, University of Venda, Private Bag X5050, Thohoyandou 0950, South Africa; Eduard.Stam@univen.ac.za

2 Department of Biological Sciences, University of Venda, Private Bag X5050, Thohoyandou 0950, South Africa; peter.tshisikhawe@univen.ac.za

3 Department of Microbiology, School of Sciences, Federal University of Technology, Akure 340252, Nigeria; alabimercy14@gmail.com

4 Ecology and Resource Management Unit, Faculty of Science, Engineering and Agriculture, University of Venda, Private Bag X5050, Thohoyandou 0950, South Africa

* Correspondence: tshianeomellda@gmail.com (T.M.N.); firstrebby@gmail.com (A.O.A.)

check for

updates

Citation: Ndou, T.M.; Stam, E.M.; Tshisikhawe, M.P.; Alabi, M.A.;

Adeeyo, A.O. Poaching of

Encephalartos transvenosus, in the

Limpopo Province, South Africa.

Resources 2021, 10, 119. https://

doi.org/10.3390/resources10120119

Academic Editors: Demetrio

Antonio Zema and Manuel

Esteban Lucas-Borja

Received: 4 August 2021

Accepted: 19 October 2021

Published: 23 November 2021

Publisher's Note: MDPI stays neutral with regard to jurisdictional claims in published maps and institutional affiliations.

\section{Copyright: (c) 2021 by the authors.} Licensee MDPI, Basel, Switzerland. This article is an open access article distributed under the terms and conditions of the Creative Commons Attribution (CC BY) license (https:// creativecommons.org/licenses/by/ $4.0 /)$.

\begin{abstract}
There is an established link between deforestation and negative hydrological effects which may affect watersheds. The number of the cycads Encephalartos transvenosus Stapf \& Burtt Davy in South Africa is drastically reducing, and they are nearly extinct. Additionally, poaching and reduction in the population of cycads in reserves may impact negatively on watersheds in protected and buffer areas since the regeneration of this plant occurs over a long period. This research aimed to study the distributions of poached cycads, evaluate the factors responsible for poaching activity and suggest possible solutions towards conservation of E. transvenosus Stapf \& Burtt Davy in some of the nature reserves in Limpopo province. Field observation was used to ascertain and collect locations of poached cycads. Data was obtained through the use of a questionnaire. Questionnaires were administered to rangers for the collection of data on causes of poaching, parts poached, measures taken and challenges of rangers in the nature reserves. Processing of the collected data was done by simple statistical analysis. The total population of rangers available in the reserves was used for the determination of the sample size of rangers by Slovin's formula. Unemployment $(46 \%)$ is the leading cause for poaching in Mphaphuli Nature Reserve, while trade is a leading factor in Modjadji and Lekgalameetse (37\% and 60\%) respectively. Debarked cycads amount to 14 (54\%) while 12 of the total (26 poached cycads) were completely removed ( $46 \%$ ). The most effective way of stopping the poaching of cycads as perceived by the rangers is by patrolling the nature reserves. The observed poaching of Encephalartos transvenosus is alarming since this plant has a low population size which is currently confined to the Limpopo Province in South Africa only. If poaching continues in the nature reserves, all cycads have the tendency of being removed. Therefore, there is a need to continually develop strategies for the conservation of cycads. The peculiar nature and challenges of each reserve have been established and unique solutions for these nature reserves in Limpopo Province have been proposed. Better conservation of cycad species can positively impact the hydrological process of the concerned area and better help the watersheds.
\end{abstract}

Keywords: watershed; hydrological processes; cycads; endangered plants; mitigation strategy; nature reserves

\section{Introduction}

The impact of forests on the regulation of water cycles and prevention of adverse hydrological events in watersheds has been reported while improper management of forest reserves has been reported for significant inter-seasonal water imbalance [1]. Africa holds a rich assemblage of cycads in forest reserves and South Africa is a major hotspot of cycads 
with 37 species in the genus Encephalartos and one belonging to the genus Stangeria. The starch-rich stems and cones of some selected species are used as food resources, and leaves are taken to make straps and baskets [2]. Cycads play important roles for dependent arbuscular mycorrhizae, birds, and obligate cycad feeders, all of which contribute to ecosystem functioning. The significant nitrogen-fixing contribution of cycads enhances soil fertility [3], and cycads can shape biogeochemical processes of their micro-habitats, thereby influencing the ecosystem's spatial heterogeneity [4].

Cycads are currently endangered due to poaching [5,6]. Though they are long-living, they are slow-growing [7]. Within the African cycads, four species of Encephalartos are already extinct in the wild, 18 are critically endangered, and 10 are classified as endangered [8]. Of the 38 cycad species in South Africa, three are labelled extinct, twelve are critically endangered, four are endangered, nine are vulnerable and seven are classified as near threatened according to the International Union for Conservation of Nature (IUCN) Red List [9]. Important cycad species are identified as 'Endangered' under the Commonwealth Environment Protection and Biodiversity Conservation Act 1999 (EPBC Act) [3]. Listed under the Convention on International Trade in Endangered Species (CITES), cycads are currently threatened with extinction [10-12]. Private collectors are prepared to pay up to R100,000 (US $\$ 15,000-\$ 20,000$ ) per meter of stem height [13], and about twenty-five species of Encephalartos are known to be sold at Durban and Johannesburg markets for medicinal purposes. Almost all human interactions with this group of plants are reportedly deleterious and the cycad populations are declining globally [3]. Encephalartos transvenosus has a localized distribution in Limpopo province, South Africa [6]. It is locally known as "Tshifhanga" in Tshivenda language or the "Modjadji cycad" in Balobedu. Encephalartos transvenosus was listed as a rare species by Hilton-Taylor et al. [14]. There is an observed consistent reduction in the number of cycads in South Africa and this has been attributed to the partial or complete removal of cycads for human use [15]. It is so severe in South African populations that it has been referred to as the "cycad extinction crisis" [2,12].

The continuous harvest of cycads will not only affect their availability and distribution but can also contribute to the hydrological imbalance of the affected area thus impacting water conservation and watershed, hence the need for their continued existence. The main aim of the study was to evaluate and suggest possible solutions to the poaching of Encephalartos transvenosus within three cycad nature reserves in the Limpopo province (Figure 1). The specific objectives include investigating the impact of rangers' experience and other parameters on poaching activities, evaluating the challenges faced by the nature reserves and mapping the distribution of poached cycads in the reserves towards better conservation. 


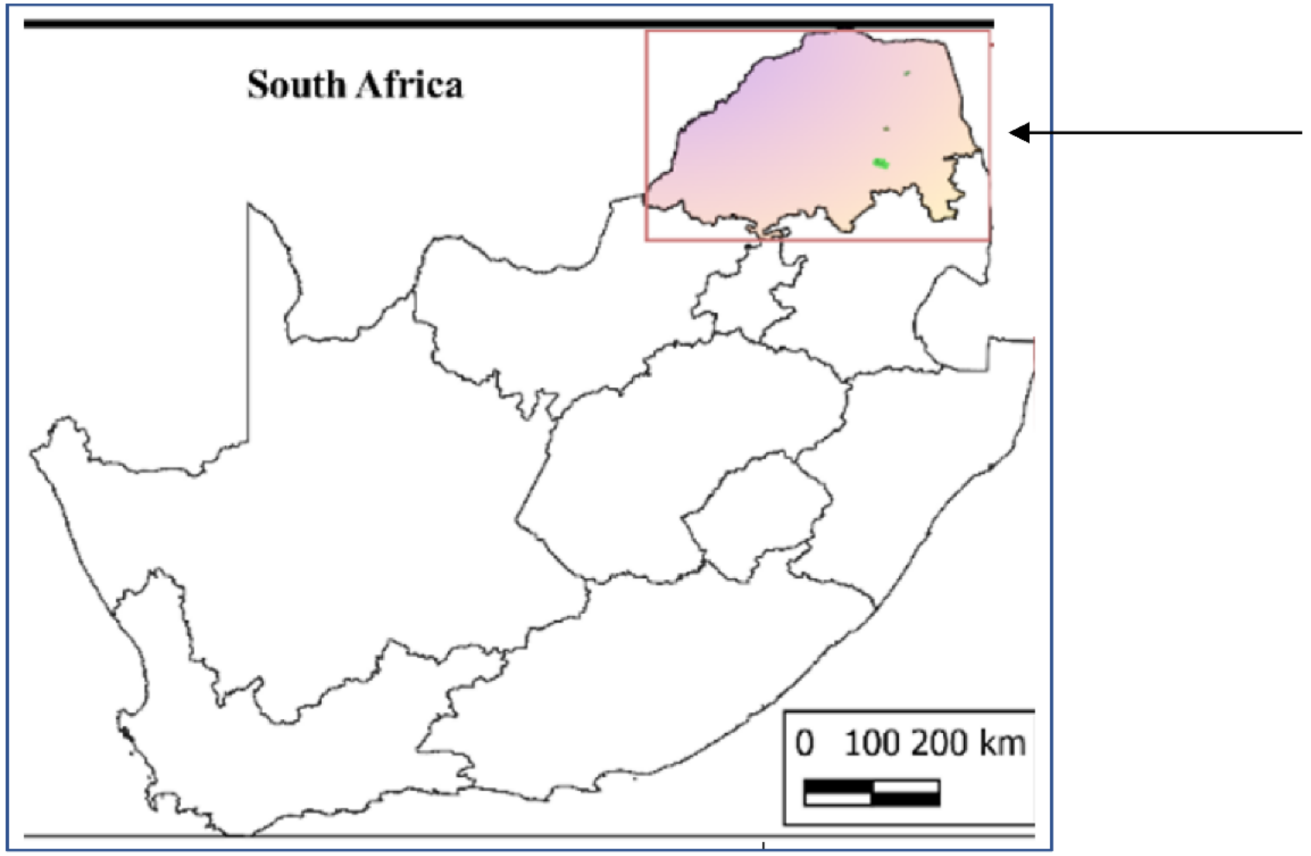

Figure 1. Study area map.

\section{Materials and Methods}

\subsection{Study Area}

The three selected areas for this study include Mphaphuli (MNR), Lekgalameetse (LNR) and Modjadji (MoNR) nature reserves in Limpopo province, South Africa. Lekgalameetse Nature Reserve is the largest of the three studied with an area of 18,718 ha followed by Mphaphuli Nature Reserve with an area of 1300 ha and the least in size is Modjadji Nature Reserve with an area of 350 ha. The Mphaphuli, Lekgalameetse and Modjadji nature reserves are in Thohoyandou $\left(22^{\circ} 48^{\prime} 18.2^{\prime \prime} \mathrm{S}, 30^{\circ} 40^{\prime} 39.0^{\prime \prime} \mathrm{E}\right)$, Northern Drakensberg of Limpopo province $\left(20^{\circ} 08^{\prime} 8^{\prime \prime} \mathrm{S}, 30^{\circ} 12^{\prime} 01^{\prime \prime} \mathrm{E}\right)$ and Modjadjiskloof $\left(23^{\circ} 37^{\prime} 25.19^{\prime \prime} \mathrm{S}\right.$, $30^{\circ} 21^{\prime} 28.79^{\prime \prime}$ E) respectively [15-17].

\subsection{Study Population and Sample Size Determination}

The sample size of 15 respondents for questionnaire administration (Appendix A) was calculated based on Equation (1). The population size of poached cycads was validated by literature [18-21]. Purposive sampling was combined with rangers' knowledge to locate poaching sites and to establish the distribution of poached cycads. Poaching was categorized according to the part of the plant poached: the roots, the fruits and seeds, bark, leaves, or the whole plant. A handheld Global Positioning System (GPS) was used to record the geolocations of poached cycads. Open-ended questionnaires were administered to rangers from all three nature reserves to establish the relationship between the challenges of rangers and poaching activities occurring inside the reserve. The questionnaire contained questions about the reason for poaching, the plant parts usually removed, the control measures used in reserves and the problems encountered by the rangers. Seven (7) questionnaires were distributed to rangers from Mphaphuli nature reserve and four (4) each were distributed to rangers from Modjadji and Lekgalameetse nature reserves. Slovin's formula Equation (1) was used to establish the population size of rangers needed for the study, which was informed by the total number of rangers (16) available in the reserves at the time of the study.

$$
\mathrm{Sz}=\frac{N}{1+N e^{2}}
$$

where $\mathrm{Sz}=$ Required sample size of the total population

$N=$ Total population size 
$e=$ Margin of error set at $95 \%$ confidence level as 0.05

\subsection{Analysis}

Data collected through an open-ended questionnaire were analysed using descriptive analyses. Data were cleaned and captured using an Excel spreadsheet. Frequency and percentages were used in the analyses of the questionnaires from the rangers. Charts were used for further presentation and interpretation of the data. The map reference coordinates collected using the GPS were recorded in an Excel spreadsheet and imported into QGIS software to create a distribution map of poached cycads in the reserves.

\section{Results}

\subsection{Demography of Rangers}

There were no female rangers in Mphaphuli and Lekgalameetse nature reserves (Table 1). In MNR, $72 \%$ of rangers have primary education only (Table 1 ). However, these rangers have extensive experience in patrolling and conservation of cycads. The results from MoNR shows that $50 \%$ of rangers have high education levels while $25 \%$ have primary education and others have a secondary education. The results from the questionnaire show that most of the rangers that work inside the reserve are above the age of 53 years. The benefit of having field rangers who have been working in a reserve for a long time is that they are experienced, which aids in proper patrolling and arrest of poachers.

Table 1. Demography of rangers.

\begin{tabular}{lccc}
\hline $\begin{array}{c}\text { Demography of the } \\
\text { Rangers. }\end{array}$ & $\begin{array}{c}\text { Mphaphuli Nature } \\
\text { Reserve (\%) }\end{array}$ & $\begin{array}{c}\text { Modjadji Nature } \\
\text { Reserve (\%) }\end{array}$ & $\begin{array}{c}\text { Lekgalameetse } \\
\text { Nature Reserve (\%) }\end{array}$ \\
\hline $\begin{array}{l}\text { Gender } \\
\text { Female }\end{array}$ & 0 & 50 & 0 \\
Male & 100 & 50 & 100 \\
Educational status & 0 & 0 & 0 \\
No formal Education & 72 & 25 & 25 \\
Only Primary & 14 & 25 & 25 \\
Only secondary & 14 & 50 & 50 \\
Higher education & 14 & 25 & 0 \\
Age of the Rangers & 0 & 25 & 50 \\
25-31 & 0 & 0 & 0 \\
32-38 & 29 & 0 & 25 \\
39-45 & 57 & 50 & 25 \\
$46-52$ & & & \\
53 and above & & & \\
\hline
\end{tabular}

\subsection{Alleged Causes of Poaching}

A total of 26 cycads (E. transvenosus) were reportedly poached in the three study sites (15 in MNR, 8 in MoNR and 3 in LNR). The alleged causes of poaching from the three nature reserves are presented in Figure 2. Based on the percentage frequency, trade is the leading cause of poaching in Modjadji and Lekgalameetse nature reserves with $37 \%$ and $60 \%$ attributed values, respectively. Medicinal application appears as another leading cause for poaching as drug manufacturing and trado-medical applications also account for a high percentage of poaching in MoNR and LNR. Medicinal use in Lekgalameetse accounts for $40 \%$ of poaching activities. It appears that unemployment $(46 \%)$ and inadequate maintenance $(18 \%)$ are other contributing factors to poaching as observed in MNR. It could be reasoned that the demand for cycads in the study area is fueled by health issues and current interest in the green economy(trado-medical and drug manufacturing applications) while unemployment and inadequate fencing are major contributors to reasons why people are easily recruited (engaged) into the poaching business. 


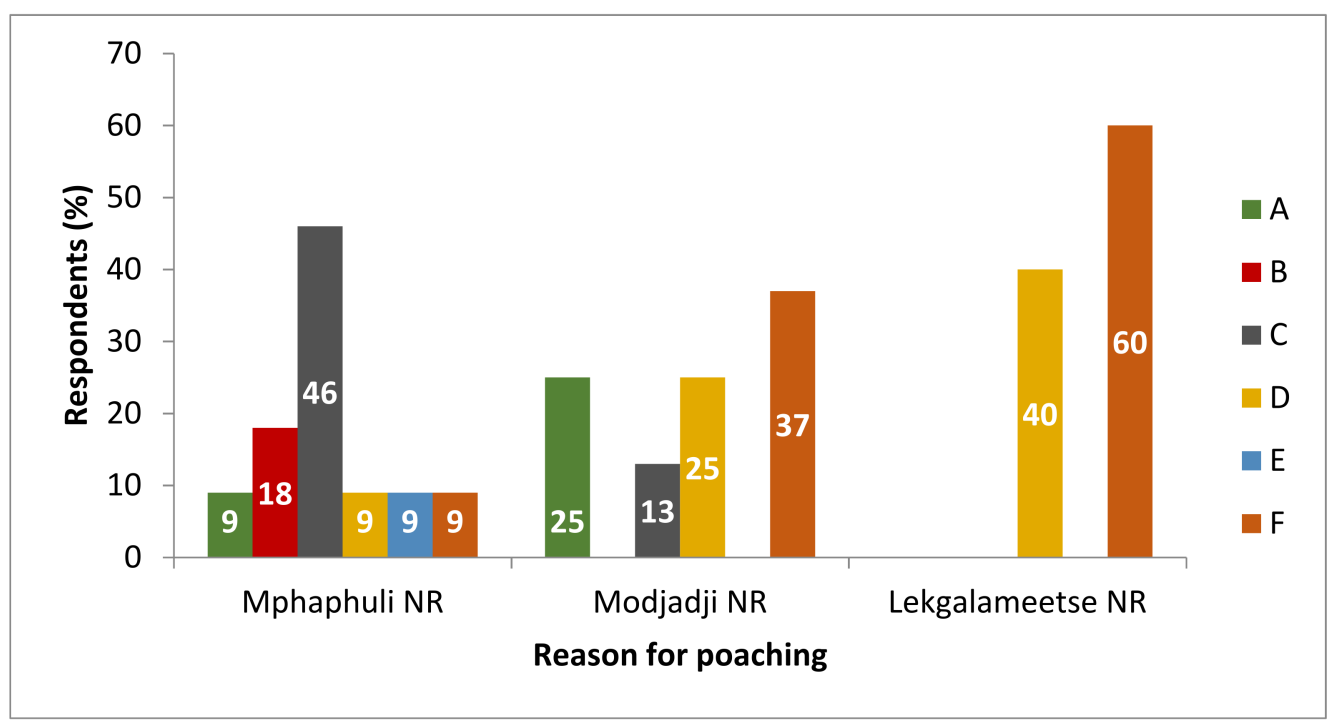

Figure 2. Alleged causes of poaching from all three Nature Reserves studied. Key: $A=D r u g$ manufacturing; $\mathrm{B}=$ Inadequate fencing; $\mathrm{C}=$ Unemployment; $\mathrm{D}=$ Traditional medicine; $\mathrm{E}=$ Pedestrian route inside the reserve; $\mathrm{F}=$ Trade; $\mathrm{NR}=$ Nature Reserve.

\subsection{Characteristics of Poaching}

The method of poaching observed depends on the topographical location of the cycads. In reference to Table 2, it could be opined that protection of areas and difficulty of access are factors contributing to the preservation of cycads. The geolocations were coded to prevent further exposure of cycads to poaching. The results from the study showed that complete removal of cycads occurred in easily accessible areas (A1) while cycads with difficult accessibility were less attractive for poaching and few completely removed cycads were reported in these areas. Easy accessibility resulted in higher frequency for completely removed cycads within the three nature reserves (A1, B1-B7, C1\&C3). Cycads that were completely removed were easier to access by the poachers.

Table 2. Coded Geolocations of poached cycads in three nature reserves studied.

\begin{tabular}{|c|c|c|c|c|c|c|c|}
\hline \multirow{2}{*}{$\begin{array}{l}\text { Nature Reserve } \\
\text { Total Poaching }\end{array}$} & \multicolumn{2}{|c|}{ Poached Cycads } & \multicolumn{3}{|c|}{ Terrains } & \multicolumn{2}{|c|}{ Accessibility } \\
\hline & $\begin{array}{l}\text { Completely } \\
\text { Removed }\end{array}$ & Debarked & Hilly & Gentle & Steep & Easy & Difficult \\
\hline $\begin{array}{l}\text { Mphaphuli } \\
\text { (15; A1-A15) }\end{array}$ & 1 (A1) & 14 (A2-A15) & 13 (A2-A14) & 1 (A1) & 1 (A15) & $1(\mathrm{~A} 1)$ & $14(\mathrm{~A} 2-\mathrm{A} 15)$ \\
\hline $\begin{array}{c}\text { Modjadji } \\
(8 ; \mathrm{B} 1-\mathrm{B} 8)^{*}\end{array}$ & 8 (B1-B8) & 0 & 8 (B1-B8) & 0 & 0 & 7 (B1-B7) & 1 (B8) \\
\hline $\begin{array}{l}\text { Lekgalameetse } \\
\quad(3 ; \mathrm{C} 1-\mathrm{C} 3)\end{array}$ & $3(\mathrm{C} 1-\mathrm{C} 3)$ & 0 & $1(\mathrm{C} 2)$ & $2(\mathrm{C} 1 \& \mathrm{C} 3)$ & 0 & $2(\mathrm{C} 1 \& \mathrm{C} 3)$ & $1(\mathrm{C} 1)$ \\
\hline
\end{tabular}

Note: Code A (A1-A15) represents geolocations of poached cycads from Mphaphuli Nature Reserve, Code B (B1-B8) represents poached cycads from Modjadji Nature Reserve and code C (C1-C3) represents poached cycads from Lekgalameetse Nature Reserve. *; poaching outside the protected portion of the reserve.

\subsection{Distribution of Poached Cycads}

Figure 3 shows the distribution of poached cycads in the Mphaphuli and Lekgalameetse nature reserves where poaching occurred within the reserves. In MNR, poached cycads were clustered close to the edge of the reserve which may account for the easy exposure of this population of E. transvenosus. Both debarking and complete removal of cycads were observed at this site. In LNR, though poached cycads are not clustered as observed in MNR, there was also complete removal of cycads close to the edge of the reserve which con- 
firms the contribution of easy accessibility to poaching. With regards to MoNR, poaching occurred outside the reserved area and all cycads poached were completely removed.

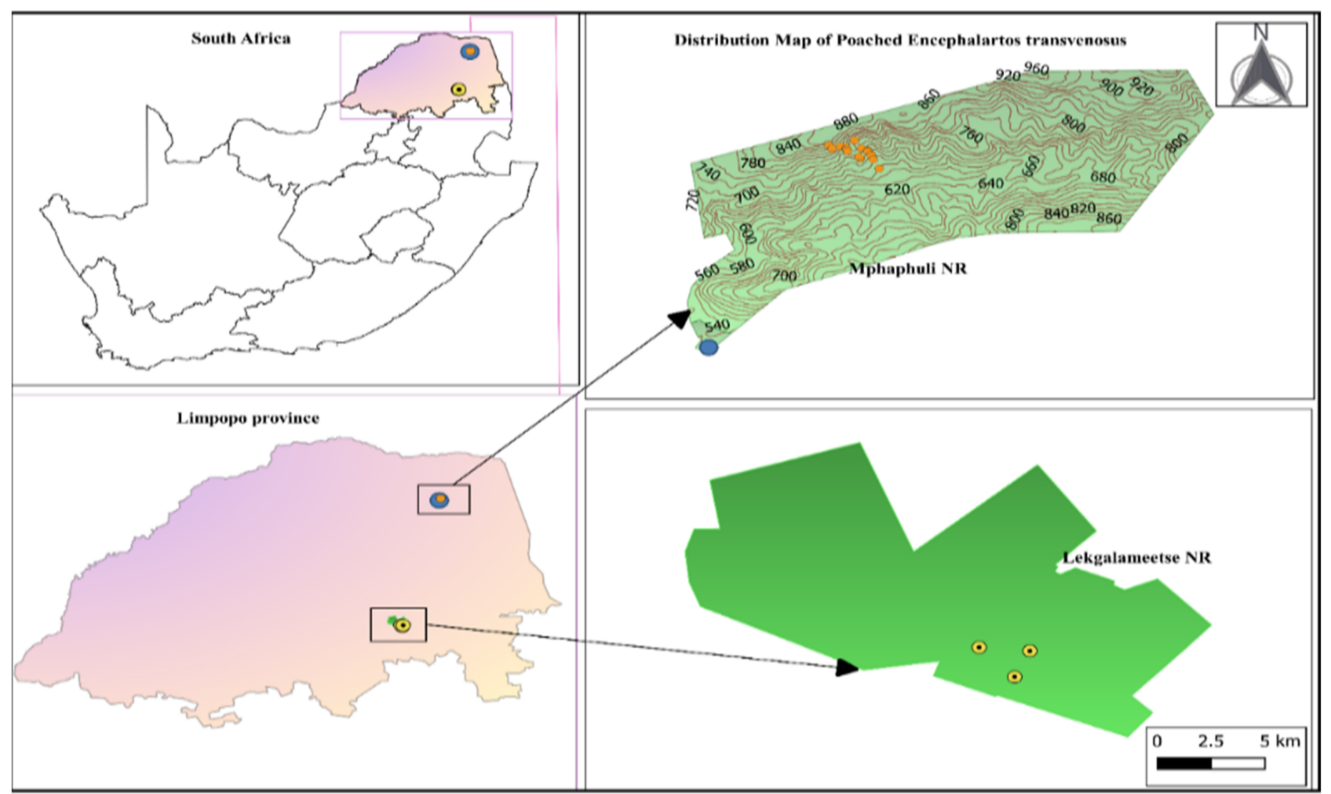

Figure 3. Distribution of poached cycads within Mphaphuli and Lekgalameetse nature reserve.

\subsection{Challenges Faced within the Reserve}

The three nature reserves studied are characterized by different challenges as presented in Figure 4. All three nature reserves indicated safety (eight respondents) and a shortage of rangers (seven respondents) as challenges faced in the reserve (Figure 3). Only in the Mphaphuli nature reserve were lack of electronic equipment and non-availability of a patrol vehicle stated as challenges. A suitable uniform is a challenge in Modjadji and Mphaphuli nature reserves. Proper walking trails and patrol vehicles were the least reasons cited for poaching. In the Lekgalameetse nature reserve, safety and shortage of rangers were the challenges encountered, while walking trails and uniforms were not reported as challenges in this reserve. The total number of challenges listed for the reserves were in the order $7(\mathrm{MNR})>4(\mathrm{MoNR})>3(\mathrm{LNR})$.

\subsection{Measures Taken to Protect the Cycads}

Figure 5 shows the various measures put in place for the preservation of E. transvenosus cycads in the three nature reserves. Planting of seedlings has not been adopted in the Modjadji nature reserve but was reported in the Mphaphuli and Lekgalameetse nature reserves as a preservation measure. Rangers cited visiting of households with cycads as a prevention measure in Mphaphuli and Modjadji, but not in Lekgalameetse. All nature reserves also reported law enforcement (Law enforcement implemented by the Limpopo Department of Economic Development Environment and Tourism; LEDET) as a way of preventing the poaching of cycads. Patrolling and law enforcement seems to be the agreed means by which poaching can be addressed as indicated by all the respondents from the three nature reserves. 


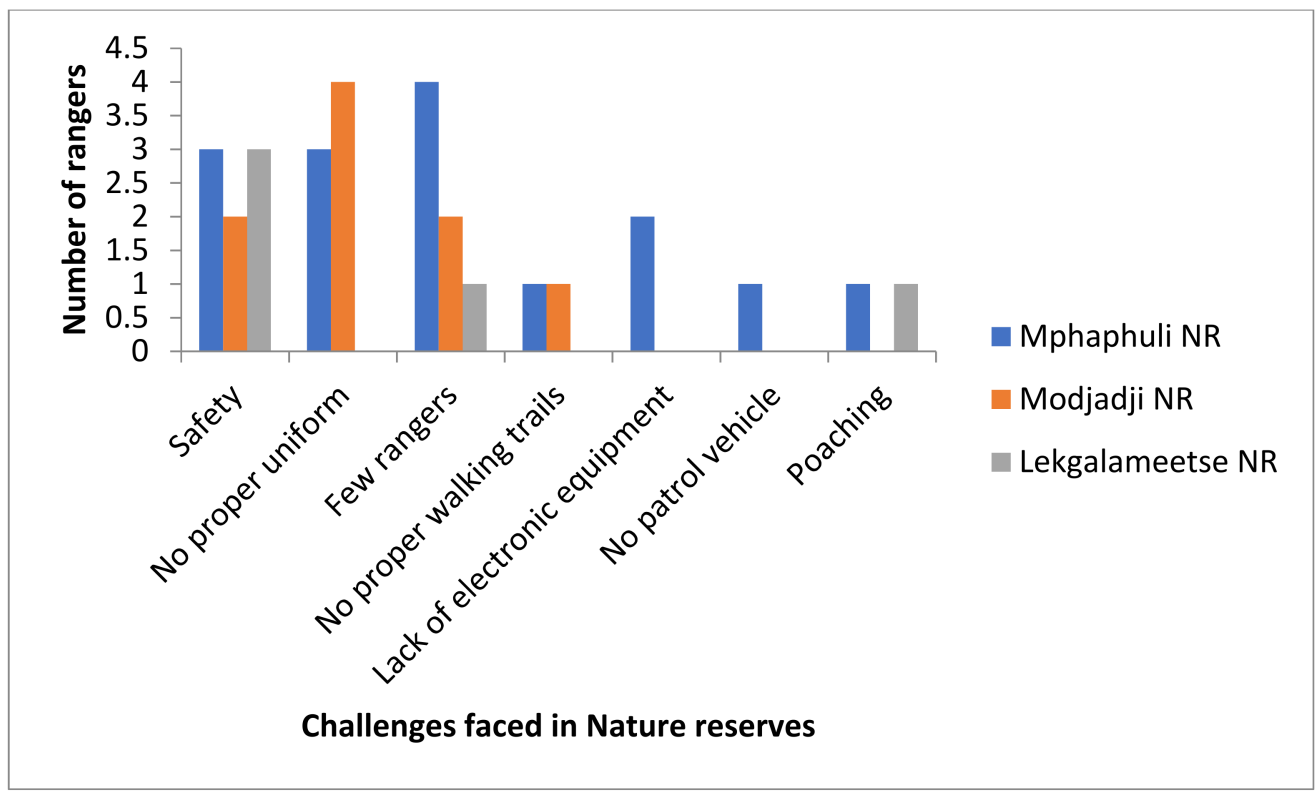

Figure 4. Challenges faced in the nature reserves as indicated by rangers. NR $=$ Nature Reserve.

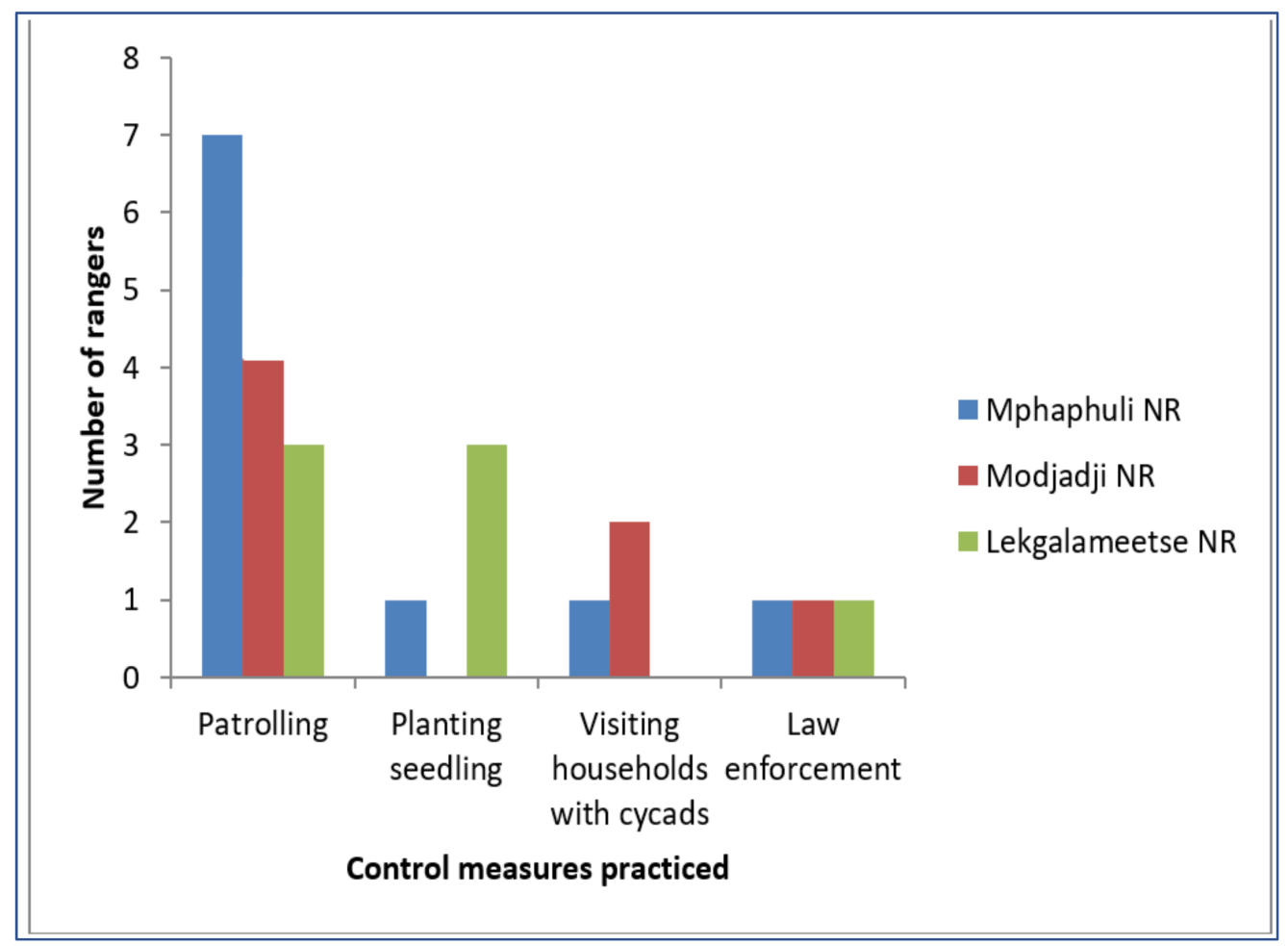

Figure 5. Measures taken to protect Encephalartos transvenosus cycads. Key: NR = Nature Reserve.

\section{Discussion}

As the human population increases, there is a consequent impact on the health sector. This has led to the current interest in traditional medicine and the green economy causing medicinal plants to receive more attention [22]. More than half of South Africans use traditional medicine [23] and traditional healers need to harvest more plants to meet the need of the growing client base. This has a major effect on both the local and global availability of medicinal plants [23]. Ravele and Makhado [15] highlighted that $68 \%$ of South African cycads have been harvested for medicinal purposes. 
Illegal trading, the use of plant parts for medicine, inadequate fencing, unemployment, and the presence of pedestrian routes in the reserves were reasons stated for the poaching of E. transvenosus (Figure 2), which agrees with the findings of Margulies et al. [24]. Poaching in Lekgalameetse was observed in the most accessible parts of the reserve. In Modjadji NR, poaching was not documented within the reserve. However, the rangers indicated complete removal of cycads which were easily accessible next to the road and located outside the reserve. This may be associated with the easy transport of the cycads by poachers [21]. Appropriate fencing aids the conservation of cycad species by limiting the access of poachers to them [25]. Forster and Holland [3] had noted that areas around major developments, townships, those not protected, those occurring on freehold, vacant crown land, road reserve or state forest pine plantations are those most immediately under threat.

Unemployment was mentioned as a factor contributing to poaching in agreement with the study of Bamigboye et al. [26]. Poaching for medicinal use of the root, leaves and bark of the cycads was reported by Ndawond'e et al. [27]. Mander et al. [28] found that the bark of $E$. transvenosus is being sold as traditional medicine by vendors in various districts across the country, and exponential growth of cycad's business in markets has been recorded in literature [29]. Although the ornamental use of E. transvenosus was not mentioned by respondents, it is sold as an ornamental at a price ranging from R6000 to R7000 [30].

The cycads in Mphaphuli nature reserve are generally big and located at higher terrains, making them difficult to access. Thus, they are usually debarked and not completely removed, meaning they are easy to transport. Distances from roads and the edges of nature reserves have been associated with human access and poaching in the literature [31]. The complete removal of plants has been discussed as threatening their continuous existence, while removal of plant bark disrupts the energy flow within the plants [21,32]. Both have a negative effect on plant life and existence. In a similar manner, the disruption of energy flow during the debarking of cycads may lead to bark damage, slow repair or ultimate mortality which could cause a population reduction $[28,33]$. Cycads are slow-growing plants, usually taking two to three years to germinate, and any disturbance to their life process by debarking constantly renders them vulnerable to extinction $[7,34]$.

The education of rangers is an important factor and results obtained revealed that rangers at least have primary education and there was no employee with no formal education. The education level of the rangers is important as this enables suitability for the use of technical equipment such as computers and consequently increases working efficiency [35]. Female rangers are fewer in the studied nature reserves with only Modjadji having female rangers (Table 1). Studies focusing on gender transformation in South Africa have confirmed that there is a slow but gradual growth of women employed in male-dominated sectors [36].

Of all measures for preventing poaching that were mentioned by rangers, patrolling can be tagged as the most effective measure having the maximum number of responses and is also supported in literature [7,34]. Due to certain limitations, surveillance was not sufficient in this study with regard to the peculiarities of the study area. Accessibility was limited in some points where cycads were located such as in mountainous areas and there is the absence of night surveillance. Though poaching was not reported in the mountainous areas, rangers could also not conduct proper surveillance services in these areas of the reserves due to the lack of necessary equipment. Lack of equipment like drones and helicopters are a major challenge impeding the accurate monitoring of cycads in the reserves. Aside from this, an insufficient number of rangers, inadequate patrol cars or a lack of them entirely, and safety devices are other challenges encountered by the rangers complicating matters of patrolling and surveillance.

To predict the hotspots for poaching, there is a need for effective security measures in reserves [37] and this study revealed that poaching takes place in locations that are easily accessible. The relationship between the number of rangers and the effectiveness of reserve conservation was described by Christensen [38]. In this study, MNR had more 
rangers and cycads but complete removal activity was reported less (Table 2). Of the three nature reserves involved in this study, Mphaphuli and Lekgalameetse have large areas and should have sufficient rangers for effective conservation work. With more rangers, there will be more effective patrols. The mere movement of rangers in nature reserves can keep harvesters away from the reserves and this will result in less poaching of cycads.

Rangers also reported the lack of electronic and safety devices against armed poachers and wild animals as challenges. Electronic equipment such as computers, radio phones, GPS, cameras, drones and anti-poaching systems (APS) would also help in better monitoring and prevention of illegal harvesting on cycads. Anti-poaching systems such as the perimeter intruder detection system (PIDS) would help in the detection of poachers as they enter the reserve and this would further help the prevention of poaching [12]. As reported by Cambron et al. [39], proper fencing of reserves with the installation of a motion sensor and laser curtains will aid in the detection of poachers and thus limit poaching. Mulero-Pázmány et al. [40] opined that upgrading surveillance with the use of drones equipped with heat-sensing and camera devices will help in detecting the location of poachers. However, the cost of purchase and maintenance, as well as the technicality of operation, need to be addressed for this approach, though these devices are very effective in conservation.

\section{Conclusions}

In the present study, unemployment, medicinal use of cycads, inadequate fencing, and pedestrian routes in the reserve were identified as contributory factors to the poaching of cycads. The topographical location and terrains of cycads is a factor influencing their rate of poaching. Cycads are both debarked and completely removed, depending on their location and size. Challenges faced by rangers in the nature reserves affect the efficiency of rangers and the rate of poaching observed. Based on the challenges reported, there is a need for erection, re-construction, or maintenance of proper fences in the studied nature reserves. Patrolling of the reserves by experienced rangers, combined with the provision of security equipment and surveillance cars, will also be advantageous to the conservation of important forest resources such as the endangered cycad species. Enactment and awareness of anti-poaching laws, and their enforcement, are other approaches that will curb illegal poaching. The peculiarity of the study area showed that the provision of cheap health services will reduce the market for cycads while employment opportunities will decrease the number of people engaging in the poaching business. Additionally, planting cycads in spots not easily accessible could result in better conservation, the preservation of rare plant and animal species, the protection of important ecosystem services, the regulation of water cycle and other biogeochemical processes, the prevention of adverse hydrological events, the preservation of watersheds by nature, and the contribution to the stoichiometric balance of nitrogen-carbon in soil chemistry and fertility.

Author Contributions: Conceptualization, T.M.N. and E.M.S.; writing-original draft preparation, T.M.N.; writing—review and editing, E.M.S., A.O.A., M.A.A. and T.M.N.; supervision, E.M.S. and M.P.T. All authors have read and agreed to the published version of the manuscript.

Funding: This research received no external funding.

Institutional Review Board Statement: The study was conducted according to the guidelines and approval of the Institutional Review Board and Ethics Committee of University of Venda and LEDET, South Africa (date of approval: 14/02/2022; Project No: SES/19/GGIS/06/1202 and 22/07/2019; Permit No: ZA/LP/198233).

Informed Consent Statement: Informed consent was obtained from all subjects involved in the study.

Conflicts of Interest: The authors declare no conflict of interest.

Ethical Consideration: Ethical clearance (reference number SES/19/GGIS/06/1220) was obtained from the University of Venda for the research (Appendix B). Additionally, a permit (reference number ZA/LP/98233) was granted from the LEDET (Appendix C) before collecting data from the nature 
reserves. The confidentiality of respondents was respected. Where respondents could not understand English, the questions were translated from English to Tshivenda or Sepedi.

\section{Appendix A. Questionnaire}

Participants: Rangers from Mphaphuli, Modjadji and Lekgalameetse nature reserve

1. Gender (?)

\begin{tabular}{|l|l|}
\hline Female & \\
\hline Male & \\
\hline
\end{tabular}

2. Educational status (?)

\begin{tabular}{|l|l|}
\hline $\begin{array}{l}\text { No formal } \\
\text { education }\end{array}$ & \\
\hline $\begin{array}{l}\text { Only primary } \\
\text { education }\end{array}$ & \\
\hline Only & \\
secondary & \\
education & \\
\hline Higher & \\
education & \\
(Tertiary) & \\
\hline
\end{tabular}

3. What age do you fall under?

\begin{tabular}{|c|l|}
\hline $18-24$ & \\
\hline $25-31$ & \\
\hline $32-38$ & \\
\hline $39-45$ & \\
\hline $46-52$ & \\
\hline 53 and above & \\
\hline
\end{tabular}

4. How long have you been working in the reserve?

5. What are your working hours?

6. What are the causes of poaching in the nature reserve?

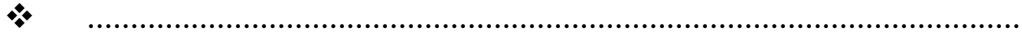


7. Which part of the Cycad species is being poached the most?

8. What is the method of poaching that poachers mostly use?

\begin{tabular}{|c|c|}
\hline Harvesting & Mark \\
Method & $(\mathrm{X} / \boldsymbol{V})$ \\
\hline Stripping & \\
\hline Debarking & \\
\hline Root & \\
\hline harvesting & \\
\hline Others (please & \\
specify) & \\
\hline
\end{tabular}

9. What is the number of poachers you have arrested?

10. What tools are mostly used by the poachers?

11. What is the government doing to reduce poaching of cycads species?

12. What are the conservation policies inside the reserve?

13. What are the measures that are taken to protect the cycads?

14. What are the challenges you face in the Nature Reserve when conserving the cycads?

15. What can you recommend to the following?

(a) The government 
(b) The community

(c) Researchers

\section{Appendix B}

\begin{tabular}{c} 
ETHISG APPROVAL CRRTFCATE \\
\hline NAME OF RESEARCHER/INVESTIGATOR: \\
MS TM NdOU
\end{tabular}

STUDENT NO:

14013715

PROJECT TITLE: Poaching of endangered Encephalartos Cycad species in Limpopo Province.

PROJECT NO: SES/19/GGIS/06/1202

SUPERVISORS/ CO-RESEARCHERS/ CO-INVESTIGATORS

\begin{tabular}{|c|c|c|}
\hline NAME & INSTITUTION \& DEPARTMENT & ROLE \\
\hline DrEM Stam & University of venda & Supervisar \\
\hline Prof MP Ishisikhawe & University of Venda & Co-Sispervisor \\
\hline MS TM NGOH! & University of Venda & Tivestigator - Student \\
\hline
\end{tabular}

The Animal, Environment and Biosafety Research Ethics Committee (AEBREC) hereby approves your project as indicated above.
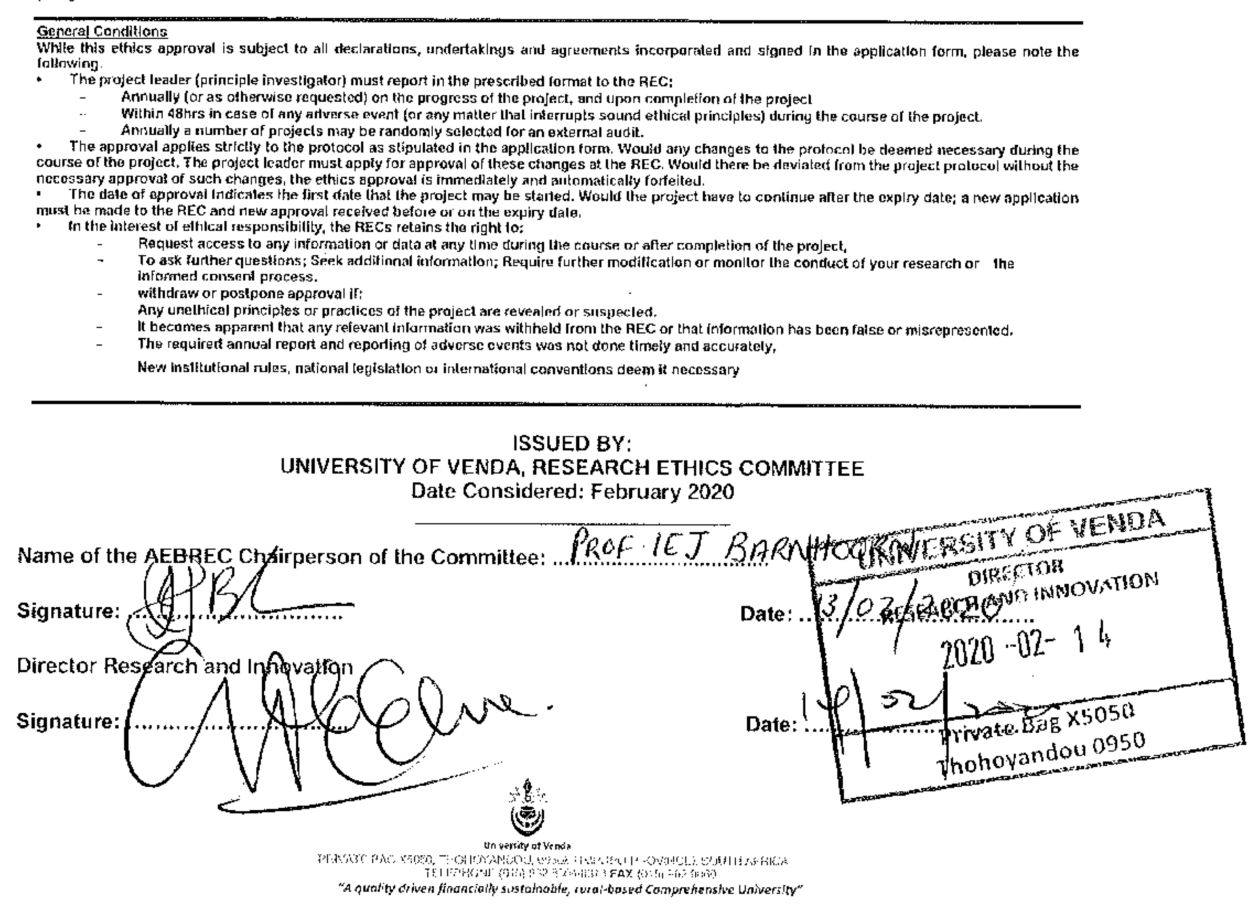

Figure A1. Ethical Clearance from the University of Venda. 
Appendix C

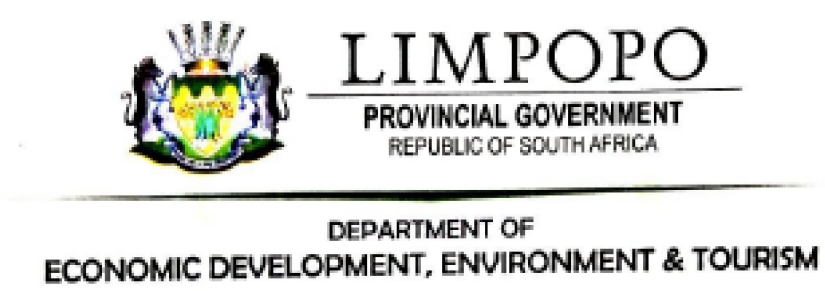

DO SCIENTIFIC RESEARCH ON PLANTS

Insued is terms of the prosibions of the Umpopo Environmental Marapement Act 2003, Act na.7 of 2003),

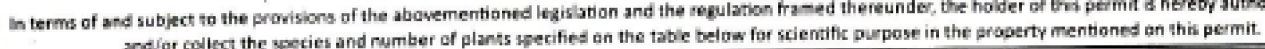

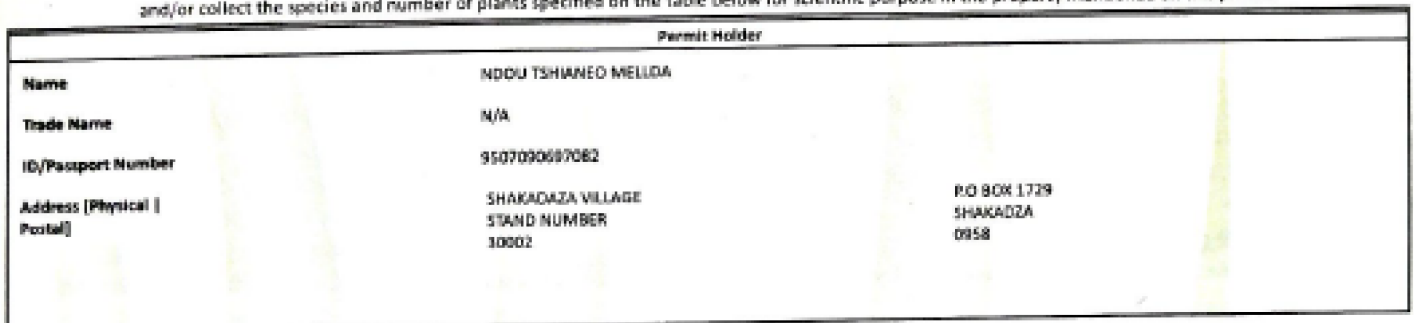

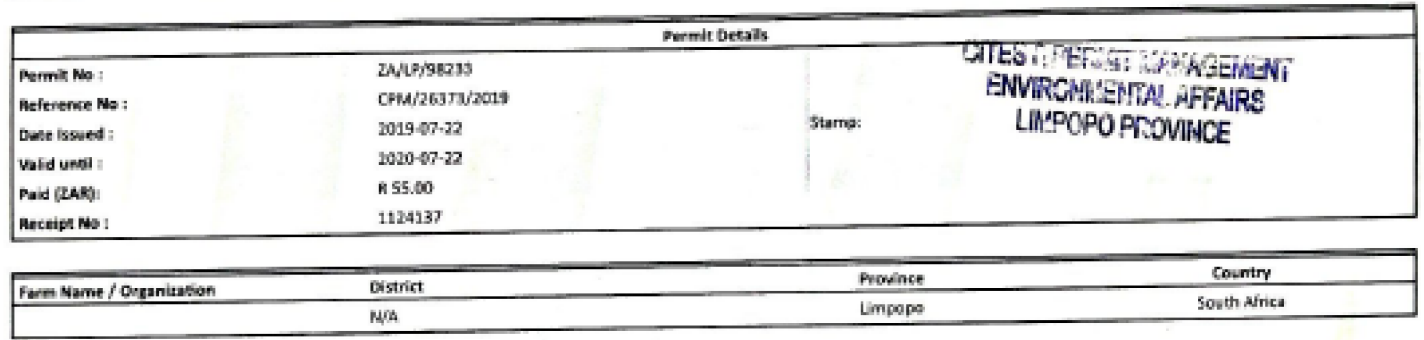

See Special Condition

WILDLIFE TRADE \& REGULATION

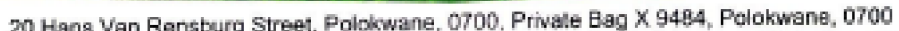

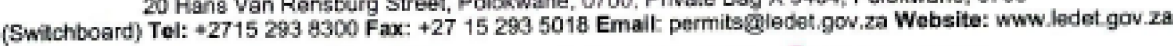

* Limpopoledet 0 ww.Facebock.com/pagesiledet (1) gLimpopolEDET

The heartland of southern Africa - development is about people!

Figure A2. Permit from LEDET. 


\section{References}

1. Hlasny, T.; Kocicky, D.; Maretta, M.; Sitkova, Z.; Barka, I.; Konopka, M.; Hlavata, H. Effect of deforestation on watershed water balance: Hydrological modeling-based approach. Lesn. Cas. 2015, 61, 89-100.

2. Retief, K. Cycad Forensics: Tracing the Origin of Poached Cycads Using Stable Isotopes, Trace Element Concentrations and Radiocarbon Dating Techniques. Master's Thesis, University of Cape Town, Cape Town, South Africa, 2013.

3. Forster, P.; Holland, A. National multi-species recovery plan for the cycads, Cycas megacarpa, Cycas ophiolitica, Macrozamia cranei, Macrozamia lomandroides, Macrozamia pauli-guilielmi and Macrozamia platyrhachis. In Queensland Herbarium 2007; Report to Department of the Environment and Water Resources: Canberra, Australia; Queensland Parks and Wildlife Service: Brisbane, Australia, 2007.

4. Marler, T.E.; Calonje, M. Two cycad species affect the carbon, nitrogen, and phosphorus content of soils. Horticulturae 2020, 6, 24. [CrossRef]

5. Li, D.Z.; Pritchard, H.W. The science and economics of ex situ plant conservation. Trends Plant Sci. 2009, 14, 614-621. [CrossRef]

6. South African National Biodiversity Institute (SANBI). National Biodiversity Assessment 2018: An Assessment of South Africa's Ecosystems, Species, and Genes. Synthesis Report; Skwono, A.L., Raimondo., D.C., Poole, C.J., Fizzotti, B., Eds.; South African National Biodiversity Institute, An Entity of the Department, Forestry and Fisheries: Pretoria, South Africa, 2019.

7. Cousins, S.R.; Witkowski, E.T.F. African cycad ecology, ethnobotany and conservation: A synthesis. Bot. Rev. 2017, 83, 152-194. [CrossRef]

8. International Union for Conservation of Nature (IUCN). IUCN Red List of Threatened Species: Encephalartos Species. 2012. Available online: http:/ / www.iucnredlist.org (accessed on 30 June 2021).

9. Bland, L.M.; Keith, D.A.; Miller, R.M.; Murray, N.J.; Rodríguez, J.P. (Eds.) Guidelines for the Application of IUCN Red List of Ecosystems Categories and Criteria, Version 1.1; IUCN: Gland, Switzerland, 2017; 99p.

10. Raimondo, D.C.; von Staden, L.; Foden, W.; Victor, J.E.; Helme, N.A.; Turner, R.C.; Kamundi, D.A.; Manyama, P.A. Red List of South African Plants; Strelitzia 25; South African National Biodiversity Institute: Pretoria, South Africa, 2009.

11. CITES. Text of the Convension. 2012. Available online: http:/ / www.cites.org/eng/disc/text.php\#II (accessed on 10 January 2021).

12. Cousins, S.R.; Williams, V.L.; Witkowski, E.T.F. Uncovering the cycad taxa (Encephalartos species) traded for traditional medicine in Johannesburg and Durban, South Africa. S. Afr. J. Bot. 2012, 78, 129-138. [CrossRef]

13. Da Silva, J.M. DNA Fingerprinting of the Critically Endangered Cycad Encephalartos latifrons, Using AFLP Markers. Master's Dissertation, University of Cape Town and South African National Biodiversity Institute, Cape Town, South Africa, 2005.

14. Hilton-Taylor, C.; Pollock, C.M.; Chanson, J.S.; Butchart, S.H.; Oldfield, T.E. State of the world's species. In Wildife in A Changing World-An Analysis of the 2008 IUCN Red List of Threatened Species; IUCN: Gland, Switzerland, 2009; p. 180.

15. Ravele, A.M.; Makhado, R.A. Exploitation of Encephalartos transvenosus outside Mphaphuli nature reserve, Limpopo Province. Afr. J. Ecol. 2009, 48, 105-110. [CrossRef]

16. Foord, S.H.; Dippenaar-Schoeman, A.S.; Jocqué, R.; Haddad, C.R.; Lyle, R.; Webb, P. South African national survey of Arachnida: A checklist of the spiders (Arachnida, Araneae) of the Lekgalameetse nature reserve, Limpopo province, South Africa. Koedoe 2016, 58, 1-8. [CrossRef]

17. Swart, C.; Donaldson, J.; Barker, N. Predicting the distribution of Encephalartos latifrons, a critically endangered cycad in South Africa. Biodiverse. Conserv. 2018, 27, 1961-1980. [CrossRef]

18. Cibrian-Jaramillo, A.; Daly, A.C.; Brenner, E.; Desalle, R.; Marler, T.E. When North and South don't mix genetic connectivity of a recently endangered oceanic cycad, Cycas micronesica, in Guam using EST-microsatellites. Mol. Ecol. 2010, 19, 2364-2379. [CrossRef]

19. Calonje, M.; Meerow, A.W.; Knowles, L.; Knowles, D.; Griffith, M.P.; Nakamura, K.; Francisco-Ortega, J. Cycad biodiversity in the Bahamas Archipelago and conservation genetics of the threatened Zamia lucayana (Zamiaceae). Oryx 2013, 47, 190-198. [CrossRef]

20. Terry, I.; Forster, P.I.; Moore, C.J.; Roemer, R.B.; Machin, P.J. Demographics, pollination syndrome and conservation status of Macrozamia platyrhachis (Zamiaceae), a geographical restricted Queensland cycad. Aust. J. Bot. 2008, 56, 321-332. [CrossRef]

21. Bamigboye, S.; Tshisikhawe, M.P. The impacts of bark harvesting on population of Encephalartos transvenosus (Limpopo cycads), in Limpopo province, South Africa. Biodiversitas J. Biol. Divers. 2020, 21, 8-13. [CrossRef]

22. Williams, T.J.; Quinton, W.L.; Baltzer, J.L. Linear disturbances on discontinuous permafrost: Implications for thaw-induced changes to land cover and drainage patterns. Environ. Res. Lett. 2013, 8, 025006. [CrossRef]

23. Van Wyk, B.E. The potential of South African plants in the development of new medicinal products. S. Afr. J. Bot. 2011, 77, 812-829. [CrossRef]

24. Margulies, J.; Bullough, L.A.; Hinsley, A.; Ingram, D.J.; Cowell, C.; Goettsch, B.; Klitgaard, B.B.; Lavorgna, A.; Sinovas, P.; Phelps, J. Illegal wildlife trade and the persistence of plant blindness. Plants People Planet. 2019, 1, 173-182. [CrossRef]

25. Hayward, M.W.; Kerley, G.I. Fencing for conservation: Restriction of evolutionary potential or a riposte to threatening processes? Biol. Conserv. 2009, 142, 1-13. [CrossRef]

26. Bamigboye, S.O.; Tshisikhawe, P.M.; Bonta, M.A. Review of extinction risks in South African cycads used for traditional medicine. S. Afri. J. Bot. 2018, 115, 279. [CrossRef]

27. Ndawond'e, B.G.; Zobolo, A.M.; Dlamini, E.T.; Siebert, S.J. A survey of plants sold by traders at Zululand muthi markets, with a view to selecting popular plant species for propagation in communal gardens. Afr. J. Range Forage Sci. 2007, 24, 103. [CrossRef] 
28. Mander, M.; Ntuli, L.; Diederichs, N.; Mavundla, K. Economics of the traditional medicine trade in South Africa: Health care delivery. South Afr. Health Rev. 2007, 1, 189-196.

29. Tshisikhawe, M.P. Trade of Indigenous Medicinal Plants in the Northern Province, Venda Region: Their Ethnobotanical Importance and Sustainable Use. Master's Dissertation, University of Venda, Thohoyandou, South Africa, 2002.

30. Skwono, A.L.; Raimondo, D.C.; Poole, C.J.; Fizzotti, B. South African National Biodiversity Assessment 2018; Slings, J.A., Ed.; 1: Terrestrial Realm; SANBI: Pretoria, South Africa, 2019; Volume 1, pp. 502-515.

31. Trombulak, S.C.; Frissell, C.A. Review of ecological effects of roads on terrestrial and aquatic communities. Conserv. Biol. 2000, 14, 18-30. [CrossRef]

32. Adeeyo, A.O.; Edokpayi, J.N.; Alabi, M.A.; Msagati, T.A.M.; Odiyo, J.O. Plant active products and emerging interventions in water treatment, food and health. Clin. Phytosci. 2021, 7, 31. [CrossRef]

33. Bakali, M.; Ligavha-Mbelengwa, M.H.; Potgieter, M.J.; Tshisikhawe, M.P. Impact of ethnobotanical utilization on the population structure of Androstachys johnsonii Prain in the Vhembe Area of the Limpopo Province. South Afr. J. For. Res. 2017, 1, 50-55. [CrossRef]

34. Donaldson, J. Cycads: Status Survey and Conservation Action Plan; IUCNCSG.2003; IUCN: Gland, Switzerland, 2003.

35. Trelova, S.; Olsavsky, F. The impact of education on employee's productivity and job satisfaction. In Proceedings of the International Technology, Education and Development Conference, Valencia, Spain, 7-9 March 2016; ISBN 978-84-608-5617-7.

36. Barker, R. The South African Labour Market: Critical Issues for Renaissance; Van Schaik: Pretoria, South Africa, 2002.

37. Young, J.A.; van Manen, F.T.; Thatcher, C.A. Geographic profiling to assess the risk of rare plant poaching in natural areas. Environ. Manag. 2011, 48, 577-587. [CrossRef] [PubMed]

38. Christensen, R.H.B. Ordinal Regression Models for Ordinal Data. Available online: Http://www.cran.r-project.org/package= ordinal/ (accessed on 10 January 2021).

39. Cambron, M.E.; Brode, C.; Butler, P.; Olszewkski, G. Poacher detection at fence crossing in Southeast Conservation. Southeastcon 2015, 2015, 1-2.

40. Mulero-Pázmány, M.; Stolper, R.; van Essen, L.D.; Negro, J.J.; Sassen, T. Remotely piloted aircraft systems as a rhinoceros anti-poaching tool in Africa. PLoS ONE 2014, 9, e83873. [CrossRef] [PubMed] 